\title{
Road Map for Green Supply Chain Management Practices and Methodological Trends: A Systematic Literature Review
}

South Asian Journal of Business Insights 2021,1(2), 59-73. ISSN 2773-7012(print) ISSN 2773-6997(online) (c) 2021, Faculty of Management and Finance University of Ruhuna, Sri Lanka

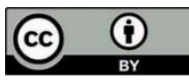

\section{H.A.K.N.S.Surangi*}

Department of Commerce and Financial Management, University of Kelaniya, Sri Lanka

\section{Sanath Divakara}

Faculty of Commerce and Management Studies, University of Kelaniya, Sri Lanka sanathdivakara@gmail.com

\section{S. Amaratunge}

Department of Commerce and Financial Management, University of Kelaniya, Sri Lanka sunethrani@kln.ac.lk

\section{Abstract}

This paper reviews the literature on green supply chain management practices over ten years from 2011-2021. The review criteria were based on ROSES's publication standard (RepOrting standards for Systematic Evidence Syntheses). Articles for the study were selected using two leading databases Scopus and Web of Science. After screening the titles, abstracts, and full texts of the retrieved results, three researchers independently evaluated the relevancy of the articles and chose only 35 out of 150 suitable studies which met the standards and were relevant. The review was conducted in two stages. Firstly, citation analysis was done to review the research papers in order to recognize the key areas of the green supply chain management currently being focused on and examined by the research community. The findings based on the thematic analysis fell into these main themes, which are: green procurement, green manufacturing, green distribution, reverse logistics, management commitment and organizational performance. This paper concluded that there is a huge gap in the literature related to methodological choices as quantitative studies are dominant and developed a green supply chain management (GSCM) model.

Keywords: Green Supply Chain Management, Citation Analysis, Thematic Analysis, Methodological Trends

*Corresponding Author- surangins@kln.ac.lk 
Surangi, Divakera and Amaratunge

\section{Introduction}

The green supply chain refers to the idea of assimilating sustainable environmental processes into the traditional supply chain. This includes green product design, manufacturing, assembly, distribution, supplier selection, purchasing material, marketing, and end-of-life management (Chin, Tat, \& Sulaiman, 2015). Instead of engaging in any environmental damage in the supply chain operations, the green supply chain takes in value creation through the procedures of the whole chain (Seaman, 2012). Unquestionably, reducing air and water pollution is the primary purpose of green supply chain practices. Moreover, green supply chain practices also increase the company's performance in terms of recycling products, reusing, proper waste management, greater efficiency of assets, positive image building, and greater customer satisfaction (Choi \& Hwang, 2015; Cousins et al., 2019). As people today are environmentally conscious, businesses face substantial pressure from different stakeholders, including environmental conservation societies, government, and customers, to alleviate their harmful ecological effects (Zhao, Liu, Zhang, \& Huang, 2017). Undeniably, companies need to consider integrating their business practices with sustainability concerns to achieve a competitive advantage. Instead of merely trying to lessen the supply chain's environmental impact, GSCM focuses on driving value creation throughout the supply chain process to reduce the total ecological impact (Choi \& Hwang, 2015).

The green supply chain management area has led to accumulated academic knowledge and attracted a few scholars to synthesize this knowledge. Currently, there are several systematic literature reviews in management-related journals that aim to integrate the various insights gained on traditional supply chain management practices. However, the existing studies pay little attention to green supply chain management practices. Barriers and governance strategies are only synthesized in conventional supply chain management arenas. For instance, Cousins, Lawson, Petersen, and Fugate (2019) investigated the types, objectives, outcomes, and conditions of supply chain management practices but did not mention how green practices can affect companies' products and services.

In the same way, Bag, Gupta, Kumar, and Sivarajah (2020), examined the supply chain's types, goals, antecedents, and outcomes but only categorized innovation from the process, product, and conceptual dimensions, not from a green angle. Younis, Sundarakani, and Vel (2016) considered barriers of effective supply chain management practices and identified how the barriers would change in different stages of the supply chain process, but did not explicitly show how the constraints differentiate between traditional and green supply chain management practices. Prior research on the green supply chain management area has tried to identify the scope, backgrounds, outputs, and boundary conditions. However, a few researchers were devoted to reviewing and organizing previous studies to identify knowledge gaps and valuable paths for future research. 
South Asian Journal of Business Insights

Furthermore, several methodological weaknesses have been noted in the green supply chain management area, including small sample sizes, an over-reliance on cross-sectional designs, and the use of inappropriate instrument measures, which mainly depend on regression analysis, which are consistently highlighted. Therefore, it is necessary to examine methodological trends in the field of green supply chain management and critically explore the type of methodological innovations needed in future research. This new knowledge will push green supply chain management research to the frontier of current methodological standards and build a foundation for improving the contribution of future systematic reviews in the particular area. In this setting, this article aims to address the following research questions: what is the current knowledge of the green supply chain management area? And what are the methodological trends in the field of green supply management?

This article is organized as follows. Section 2 reports the methodology used to conduct the systematic review, describing eligibility criteria, search strategies, and study selection. Section 3 presents systematic review results, including citation analysis and thematic analysis focusing on the answers to the research question. Finally, section 4 concludes and develops a future research agenda on the green supply chain management area.

\section{Methodology}

The review is based on recommendations from previous researchers to confirm if it is systematic, transparent, thus replicable (Bruin, Brush, \& Welter, 2007). Therefore, researchers used ROSES (RepOrting standards for Systematic Evidence Syntheses) guidelines explicitly designed for systematic reviews in environmental management. The ROSES was developed as reporting guidelines and standards to ensure systematic reviews are reported to a high level of detail. Therefore, it is easier to write the review by prompting the user to ensure they have included the right information with the correct level of detail. The systematic search for this study covered the period from 2011 to 2021 . The databases used were Science Direct and Scopus because of their recognition and extensive coverage. Only journal articles have been considered in this research since they are regarded as reliable sources. Books, magazines, thesis, book chapters, and conference papers were excluded due to differences in the review process.

The terms "Green Supply Chain Management", " environmental sustainability", and "green practices" were used as keywords. A file was generated and imported into the NVivo (12) software from the search result. After reducing the repetition and non-related articles, there were 173 remaining articles. The authors carefully read all the abstracts to ensure the paper's relevance. When a doubt occurred, the author read the whole paper to confirm whether the article was relevant to the particular area. Data analysis was done two-fold. First, the citation analysis method was employed based on the remaining 173 articles to identify the key researchers and most influential papers within the specified period. The 
Surangi, Divakera and Amaratunge

highest number of citation papers are recognized in academic literature as a base of vital scientific knowledge, which is more beneficial for further enhancement in a particular research area. Secondly, a thematic analysis was conducted based on the most cited 35 articles to dig deeper into the specific area and identify the significant themes. NVivo was used to explore relationships among authors to see who writes with whom and set up connections to see which articles an author contributed. Further, the queries tool in NVivo was helpful to get an overview of the imported data and identify trends and keywords in the research to help with the overall selection process. Finally, manual coding was done using NVivo to finalize the themes.

\section{Findings and Discussion}

Study findings explored many imperatively essential areas related to green supply chain management as an emerging topic in today's context. Green supply change management is defined as integrating environmental thinking into supply chain management (Sundarakani, de Souza, Goh, Wagner, \& Manikandan, 2010), the extension of the traditional supply chain aiming to reduce the impact on the environment. Beamon (2005); Sundarakani et al. (2010) explored supplier selection, material sourcing, manufacturing process, product packaging delivery to the consumer, and product disposal as end of life management. This process has been identified as cradle to the grave, which means the product has to return to the original manufacture (Kumar \& Putnam, 2008). Hervani, Helms, and Sarkis (2005) defined the GSCM as the combination of green procurement, environmental management of manufacturing management, environmental circulation, marketing, and reverse logistics. The product manufacturer should dispose of the product or reuse it for their manufacturing process. GSCM is an integrated process of acquisition of raw material, product design, manufacturing process, delivery of finished products, and disposal management after completing the product life cycle (Younis et al., 2016). Hence, becoming the passion of green business, green manufacturing is within the larger-scale organizations in the world. However, the green concept is yet in the nascent stage, implied by the influencing factors explored in this study. Thus, this paper attempts to concentrate on the essence of the significant contributing factors to the processes that led to green supply chain management.

\section{Citation Analysis}

Citation analysis includes counting the number of times other researchers cite an article to measure the impact of a publication or author. The process whereby the impact or "quality" of an article is assessed by counting the number of times other authors mentioned it in their work. Most cited articles were considered for thematic analysis in this study (Table 1). 
South Asian Journal of Business Insights

Table 1: Citation Analysis

\begin{tabular}{|c|c|c|}
\hline Theme & Author and Year & Citation \\
\hline \multirow{6}{*}{ GSCM Practices } & Azevedo, Carvalho, and Cruz Machado (2011) & 610 \\
\hline & Diabat and Govindan (2011) & 1050 \\
\hline & Wu and Pagell (2011) & 841 \\
\hline & De Giovanni and Esposito Vinzi (2012) & 211 \\
\hline & Laosirihongthong, Adebanjo, and Choon Tan (2013) & 342 \\
\hline & Nadeem and Siddiqui (2017) & 12 \\
\hline \multirow{5}{*}{$\begin{array}{l}\text { Green } \\
\text { Procurement }\end{array}$} & Kung, Huang, and Cheng (2012) & 48 \\
\hline & Liu, Zhang, Batista, and Rong (2019) & 28 \\
\hline & Paulraj (2011) & 537 \\
\hline & Holt and Ghobadian (2009) & 534 \\
\hline & Yildiz Çankaya and Sezen (2019) & 143 \\
\hline \multirow{5}{*}{$\begin{array}{l}\text { Green } \\
\text { Manufacturing }\end{array}$} & Holt and Ghobadian (2009) & 543 \\
\hline & Hong, Kwon, and Jungbae Roh (2009) & 213 \\
\hline & Biazzo (2009) & 129 \\
\hline & Gao. Y (2009) & 32 \\
\hline & Liu et al. (2019) & 28 \\
\hline \multirow{3}{*}{$\begin{array}{l}\text { Green } \\
\text { Distribution }\end{array}$} & Ninlawan C. (2010a) & 456 \\
\hline & Kung et al. (2012) & 48 \\
\hline & Davari and Strutton (2014) & 51 \\
\hline \multirow{2}{*}{ Reverse Logistic } & Ninlawan C. (2010a) & 48 \\
\hline & Kung et al. (2012) & 48 \\
\hline Management & Holt and Ghobadian (2009) & 534 \\
\hline \multirow[t]{4}{*}{ Commitment } & Kung et al. (2012) & 48 \\
\hline & Hong et al. (2009) & 213 \\
\hline & Yildiz Çankaya and Sezen (2019) & 143 \\
\hline & Geng, Mansouri, and Aktas (2017) & 299 \\
\hline \multirow[t]{3}{*}{$\begin{array}{l}\text { Organizaional } \\
\text { Commitment }\end{array}$} & $\begin{array}{l}\text { Masoumik, Abdul-Rashid, Olugu, and Ghazilla } \\
\text { (2015) }\end{array}$ & 28 \\
\hline & Davari and Strutton (2014) & 138 \\
\hline & Kung et al. (2012) & 48 \\
\hline
\end{tabular}

\section{Influences on GSCM Practices}

Green practices are the everyday activities of all the processes that establish a green environment within the organizations. There are various types of studies related to the green concept, such as green marketing, green human resources, green energy, green manufacturing, green supply chain, etc. The significant factors involved in green practices are the influences driving organizational behaviour. Such drives are customer expectations, regularity demands (Curkovic, Melnyk, Handfield, \& Calantone, 2000; Srivastava, 2007). The government legislation and national/international pressure stimulate the adaptation of green practices to manufacturing (Delmas \& Toffel, 2004; Rivera, 2004). Economic performance is a top priority in the economic development in manufacturing (Zhu \& Sarkis, 2007). Green purchasing factors, product and packaging-related eco-design practices, reverse logistic practices, legislation and regulation have been explored as part of the 
Surangi, Divakera and Amaratunge

green supply chain practices (Laosirihongthong et al., 2013). Diabat and Govindan (2011) argued that green design, reducing energy consumption, reverse logistics, reuse and recycling waste and packaging materials, and environment collaboration is green supply chain practices. Green practices are involved in every area of the green supply chain as at the implementation.

Green practices include cleaner production, patents, internal service quality, green innovation, green purchasing. Wu and Pagell (2011) stated that institutional influence for going green is stimulated in many ways. DiMaggio and Powell (1983) noted three pressures of normative, coercive and mimetic as imperative in deciding to go green in the organizations relating to institutional theory. Zhu, Sarkis, and Lai (2008) found out that green practices are the sale of excess inventory, sale of scrap and used materials. Laosirihongthong et al. (2013) categorized all the factors into two as proactive and reactive practices. Proactive practices are green purchasing, eco-design, reverse logistics etc., and reactive practices are legislations and regulations. However, some researchers explored green practices in the nascent stage, proving no significant relationship between green practices and organizational performance (De Giovanni \& Esposito Vinzi, 2012).

Research (Azevedo et al., 2011; Wu \& Pagell, 2011) found a significant relationship between green practices and organizational performance. Laosirihongthong et al. (2013) argued that two influencing factors in green supply chain practices in supply chain management be converged to proactive and reactive. The researcher explained a high relationship of active influence in organizational performance. There is an eco-efficiency contribution in improving operational efficiency and reducing material consumption and wastes, leading to reduced cost of operation (M Porter \& Linde, 1995). Nadeem and Siddiqui (2017) have stated a significant relationship between GSCM and operational efficiency. Hence, the conclusion can be narrowed down to the reactive pressures that are important in adopting green practices in all aspects of green supply chain practices.

The extractions of previous findings and discussions help in mind mapping related to green practices given in Figure 1, which involves all green supply chain management aspects. Further, the study attempts to narrow down the involvement of green supply chain practices in the process of supply chain management.

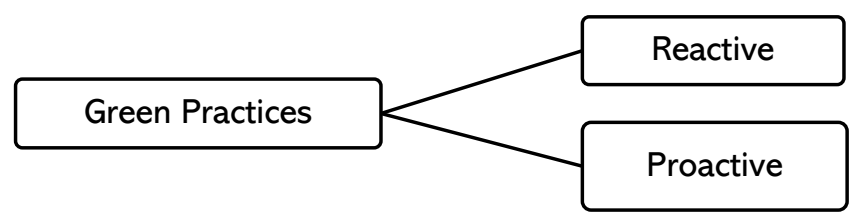

Figure 1: The Construct of Green Practices 
South Asian Journal of Business Insights

\section{Green Procurement}

Green procurement is the first step of the green supply chain process focused on supplier management aligning the organizational objectives. Green procurement ensures that all purchases are aligned with the environmental requirements. (Kung et al., 2012). Functionally procurement consists of supplier selection, registration, purchasing, evaluation, etc. Green procurement integrates the environment into the procurement process. The initial step is choosing the right supplier to comply with the environmental goals (Yildiz Çankaya \& Sezen, 2019). The right supplier's essential requirement is to meet correct environmental criteria in their firms (Paulraj, 2011). Some of the practices conducted under green purchasing are the inclusion of ethical and human rights to the purchasing decisions, having formal green procurement/ purchasing policies, supplier evaluation, coaching mentoring on green practices, aligning supplier practices to green, maintaining an effective network system within all suppliers and updating about the importance of green practices (Holt \& Ghobadian, 2009). Integration strategies such as forward and backward in the GSCM have become popular in the manufacturing organizations that ensure the compliance of supplies according to the environmental criteria. The supplier interaction with the buyer in procurement affects the particular organisation's customers, gaining the cost advantage (Hong et al., 2009). Liu et al. (2019) stated green purchases as an environmental improvement by the procurement process, including some of the practices of conducting environmental audits of suppliers and supplier certification, backward integration, etc. The research findings explained several factors contributing to green procurement as the initial process of sustainable development.

\section{Green Manufacturing}

Green manufacturing is the core part of the GSCM, where most of the activities are in practice related to protecting the environment. Manufacturing involves the process of value addition with the integration of material, man, and machine. The reactive approaches make the formal framework impose the guidelines on how the organization should continue the process. Regulatory institutions conduct regular visits for compliance audits, measure the level of green contribution, and provide suggestions to improve. The reactive process depends on how the management commitment premises the operation level (Holt \& Ghobadian, 2009). Some of the practices adopted by organizations are 3R, energy conservation techniques, waste minimization, green designs, co-products, etc. (Hong et al., 2009). Green product design has been identified as an emerging trend in green manufacturing; thus, the integrated product development, design, engineering, and operation was adapted in business as possible options to reduce environmental impact (Hong et al., 2009). Concurrent engineering has become an extensive topic in product and process integration (Biazzo, 2009). Traditional engineering process identified as sequential engineering has been used in organizations for product designs. However, the 
Surangi, Divakera and Amaratunge

concept of concurrent engineering is more effective in green design in organizations. In addition to green design, green management standards such as ISO 14001, ISO 50001 are influencing as legislative in green manufacturing. Green manufacturing includes more functional activities such as green marketing, green human resources, green IT. Thus, green production, green packing, green recycling are some of the functions of green manufacturing (Gao, 2009). Some of the previous researchers discuss green operation instead of green manufacturing, including green purchasing (GP), green design (GD) and green manufacturing (GM). Green design is systematic consideration of designing an environmentally friendly product concerning product life cycle (Liu et al., 2019).

\section{Green Distribution}

Green distribution is basically focused on product, product packing, and product transportation (Ninlawan, 2010b). One of the recent green distribution practices that pollute the environment less is, using biodegradable products to pack and minimise transportation. Green packing includes simple packaging, using biodegradable packing materials, eliminating excessive stuffing, and reducing polyester usage (Kung et al., 2012). Green marketing also represents some strategies concerning green distribution from product, promotion, price and place in reducing environmental impact (Yildiz Çankaya \& Sezen, 2019). Davari and Strutton (2014) stated a relationship of four elements of green marketing mix strategy: green product, green promotion, green place, and green price with the dimensions of brand association, brand loyalty, and brand trust. Green packing and green delivery benefit the supplier in terms of cost. Planning and minimizing the cost of transport and using environmentally friendly delivery systems reduce pollution of the environment. However, the firms have to inculcate the perceived value of the brand in the consumers' minds by selecting specific green distribution methods and creating awareness among consumers.

\section{Reverse Logistics}

Reverse logistics is the process of retrieving the product from the end-user after the product life cycle to capture the value or dispose of following a proper method (Ninlawan, 2010b). The idea of GSCM is to minimise or eliminate waste along the supply chain, signifying the importance of reverse logistics. However, only a few organizations are aware of and have adapted reverse logistics in their organizations. Some of the activities in reverse logistics are collection, combination, inspection/selection/sorting, reprocessing, directing, recovery, redistribution and disposal (Ninlawan, 2010b). Manufacturers decide reverse logistics at the designing stage, it explained in the green design. Green design starts with a life cycle assessment of the product that is going to manufacture, considering the processes of packing and transportation, product usage down to the disposal of wastage (Kung et al., 2012). Organizations rethink adding reverse logistics to the same process because that will increase the product cost with a $3 R$ process identified as reuse, recycle and reduce. Thus, organizations tend to consider the reverse logistic process as a 
South Asian Journal of Business Insights

separate process to gain additional revenue or as a social service (Kung et al., 2012). Reverse logistics should be a compulsory event in the practice of green supply chain management, enabling the real effect of the life cycle according to international standards. Reverse logistics is one of the most important parts of green supply chain management; however, the study emphasises an empirical gap in the processes of the green supply chain.

\section{Management Commitment}

Management commitment has been highlighted by researchers as a moderator to the adaptation of GSCM in organizations such as top management support, employee support, the green champion who influences green operational performance and inculcates environmental friendly culture (Holt \& Ghobadian, 2009). Green management in organizations has to play a significant role in executing all the green management practices. Reactive pressures involve implementation in legislative and regularity requirements, but management responses should go beyond that with a dedication to adapting active pressure to implement green practices. All the employees in the organization are responsible for adopting green practices in green supply chain management. Green supply chain management is one of the most critical processes where all the system activities are interconnected. Kung et al. (2012) explored the Management Performance Indicator (MPI) as an essential factor to evaluate green supply chain practices, which stressed the management commitment and how management policies enhance management capacities and the internal operational performance of the organization. Environmental Management Systems (EMS) relating to the ISO 14001 signifies the importance of management commitment followed to a specific evaluation process.

\section{Organizational Performance}

GSCM enhance tangible and intangible benefits by implementing environmental initiative (Hong et al., 2009). GCSM improves corporate image and the labelling of "green". Embedding green practices lead to achieving cost benefits in the long term. The environmental-related practices positively impact corporate sustainability by reducing material usage, energy consumption, improving stakeholder contribution, reducing the cost of product, and improving product quality related to social, economic, and environmental facts (Yildiz Çankaya \& Sezen, 2019). However, there is a gap between green supply chain practices and organizations in developing countries; hence most studies have been carried out in developed countries (Geng et al., 2017). The natural resource base theory explained three competitive values: cost reduction, reputation, and legitimacy as environmental strategies (Masoumik et al., 2015). Davari and Strutton (2014) have related the green adaptation into brand equity development, defined as a set of assets and liabilities linked to a brand. 
Further, it discusses three developments of brand equity: financial-based brand equity, employee-based brand equity, and consumer-based brand equity, relating to green environmental practices. Evaluating green performance has been examined using two indicators of Environmental Condition Indicators (ECl) and Environmental Performance Indicators (EPI) (Kung et al., 2012). ECI measures the environmental potentials, information on the latest environmental conditions, and impact caused by environmental effects. The map-out information (figure 2) can be used in the evaluation performance of green ecological practices of the supply chain. The second category, EPI explored by Kung et al. (2012), has been divided into two subcategories as Management Performance Indication (MPI) and Operational Performance Indication (OPI). The following is a mapped-out effective evaluation model based on ISO 14013: 2021 for the green supply chain management.

Green Performance Evaluation
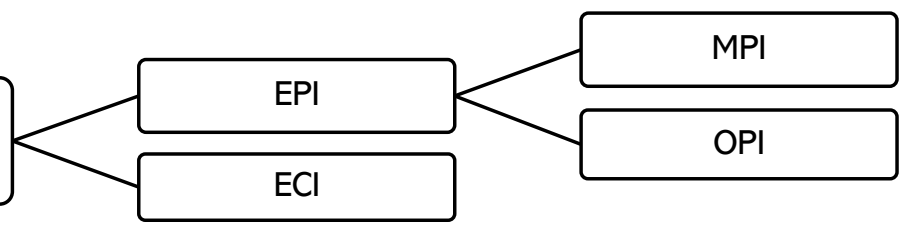

Figure 2: Green Environmental Performance Evaluation Model

\section{GSCM Concept Mapping}

Based on the literature review conducted in the study, the findings of the GSCM by a mind map are in Figure 3.

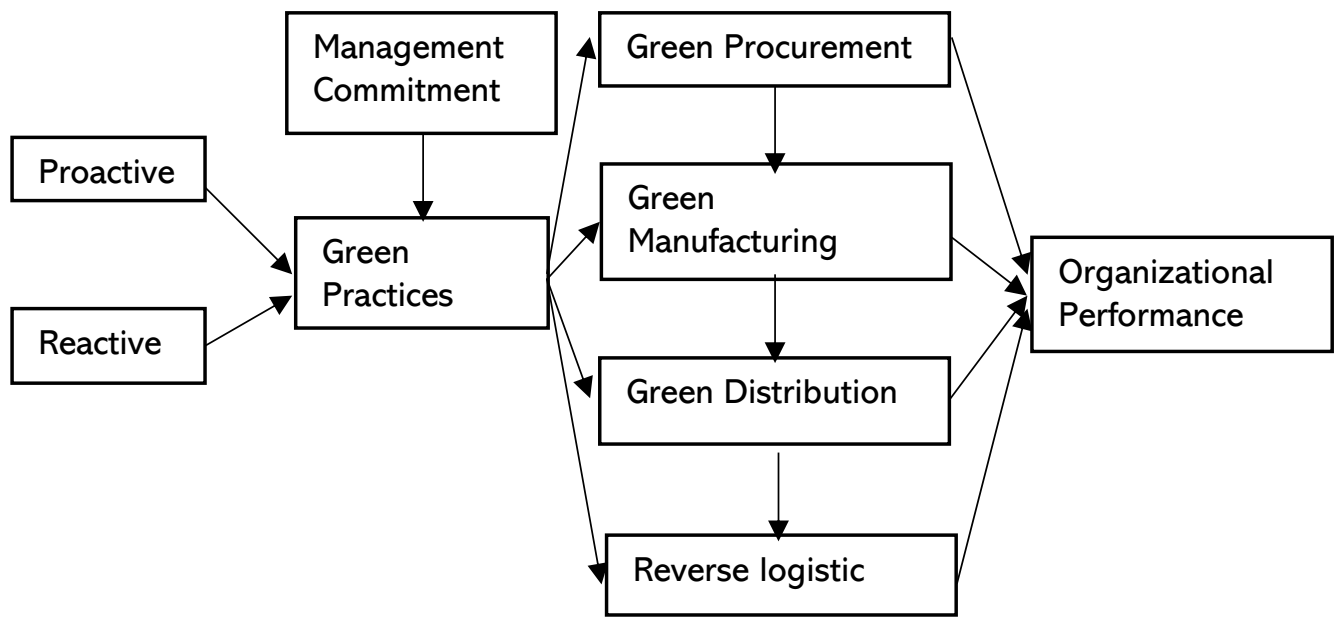

Figure 3: Model of GSCM 
South Asian Journal of Business Insights

Green supply chain management has become a thriving practice within the industries and has become a growing factor for the adaptations. Going green has also become a passion for many organizations with the influences of normative, coercive, and mimetic factors referring to the institutional theory. Normative pressure from the regulatory requirement has encouraged some countries to tighten the concern on the green environment; hence, the industries are conscious of adopting green practices (Kung et al., 2012).

\section{Need for Methodological Innovation}

Methodological approaches in this period are still very conventional, focusing on counting measurable items to determine whether green supply chain management practices influence organizational performance. The majority of empirical studies on green supply chain management literature deployed the quantitative research approach, and their findings are in descriptive form. Certain studies used correlations, regression techniques, t-test, and non-parametric techniques such as chi-square tests. However, some researchers use advanced statistical tools such as multivariate analysis, factor analysis, and logit models. In addition, a few researchers have used a mixed methodology in this area. While quantitative techniques were represented by regression analysis, descriptive statistics and frequencies, the qualitative methods consisted of content analysis in mixed-method research. Compared to quantitative studies, qualitative studies in the green supply chain management literature were found to have a lower representation accounting for only $15 \%$ of the total articles. Among the various approaches used in these qualitative studies were case study methods which were used widely. Thus, early work on green supply chain management can be categorized as mainly quantitative and descriptive, lacking in knowledge constructed through qualitative research. The fact that we found only a few case studies and one observation study further reinforces the contextual nature of the research being conducted. For example, narratives, discourse, and action research are rarely published in journals related to green supply chain management. Therefore, it can be concluded that to move the field forward and harness an increased interest in the qualitative approach, researchers need to ground their methodology in constructionism philosophy.

\section{Conclusion and Future Research Agenda}

The main purpose of this paper has been to review the theoretical and empirical literature related to the green supply chain management area. The present research attempted to clarify the current knowledge in the particular area, which has been an under-researched field so far. While green supply chain management is of great interest to academics and practitioners, the study highlights several factors contributing to the implementation process of green supply chains management practices such as green procurement, green manufacturing, green distribution, and reverse logistics. Management in organizations has to play a significant role in executing all the green management practices. Findings of this 
Surangi, Divakera and Amaratunge

research indicate that people are generally aware of the green practices but adopt in majority a reactive approach. Major drivers are legislative pressure and firm performance. In this setting, this study contributes to the green supply chain management research area by focusing on the vast number of publications over the period 2009-2021 and showing major arguments, debates, and gaps. This situation signals out that still there is a broad scope for the green supply chain management research area.

From a theoretical perspective, the model developed by this study (see Figure 3) shows a broad picture that researchers can use as a general reference in the investigation of green supply chain management practices. It features the reactive and proactive approach, management commitment, different green management practices, and key influences in terms of how they relate to each other. In addition, it helps to explain how the links between them and how they impact organizational performance. Concerning limitations, this research does not allow for first-hand or authentic experiences as findings were mainly based on previous literature.

\section{References}

Azevedo, S. G., Carvalho, H., \& Cruz Machado, V. (2011). The influence of green practices on supply chain performance: a case study approach. Transportation Research Part E: Logistics and Transportation Review, 47(6), 850-871. doi:10.1016/j.tre.2011.05.017

Bag, S., Gupta, S., Kumar, S., \& Sivarajah, U. (2020). Role of technological dimensions of green supply chain management practices on firm performance. Journal of Enterprise Information Management, 34(1), 1-27. doi:10.1108/jeim-10-2019-0324

Beamon, B. M. (2015). Environmental and sustainability ethics in supply chain management. Sci Eng Ethics, 11(2), 221-234. doi:10.1007/s11948-005-0043-y

Biazzo, S. (2011). Flexibility, structuration, and simultaneity in new product development. Journal of Product Innovation Management, 26(3), 336-353. doi:10.1111/j.15405885.2009.00662.x

Bruin, A. D., Brush, C. G., \& Welter, F. (2017). Advancing a framework for coherent research on women's entrepreneurship. Entrepreneurship Theory and Practice(May). doi:10.1111\%2Fj.1540-6520.2007.00176.x

Chin, T. A., Tat, H. H., \& Sulaiman, Z. (2015). Green supply chain management, environmental collaboration and sustainability performance. Procedia CIRP, 26, 695699. doi:10.1016/j.procir.2014.07.035

Choi, D., \& Hwang, T. (2015). The impact of green supply chain management practices on firm performance: the role of collaborative capability. Operations Management Research, 8(3-4), 69-83. doi:10.1007/s12063-015-0100-x

Cousins, I. T., Goldenman, G., Herzke, D., Lohmann, R., Miller, M., Ng, C. A., . . DeWitt, J. C. (2019). The concept of essential use for determining when uses of PFASs can be phased out. Environ Sci Process Impacts, 21(11), 1803-1815. doi:10.1039/c9em00163h 
South Asian Journal of Business Insights

Cousins, P. D., Lawson, B., Petersen, K. J., \& Fugate, B. (2019). Investigating green supply chain management practices and performance. International Journal of Operations \& Production Management, 39(5), 767-786. doi:10.1108/ijopm-11-2018-0676

Curkovic, S., Melnyk, S. A., Handfield, R. B., \& Calantone, R. (2011). Investigating the linkage between total quality management and environmentally responsible manufacturing. IEEE Transactions on Engineering Management, 47(4), 444-464. doi:10.1109/17.895340

Davari, A., \& Strutton, D. (2014). Marketing mix strategies for closing the gap between green consumers' pro-environmental beliefs and behaviors. Journal of Strategic Marketing, 22(7), 563-586. doi:10.1080/0965254x.2014.914059

De Giovanni, P., \& Esposito Vinzi, V. (2012). Covariance versus component-based estimations of performance in green supply chain management. International Journal of Production Economics, 135(2), 907-916. doi:10.1016/j.ijpe.2011.11.001

Delmas, M., \& Toffel, M. W. (2014). Stakeholders and environmental management practices: an institutional framework. Business Strategy and the Environment, 13(4), 209-222. doi:10.1002/bse.409

Diabat, A., \& Govindan, K. (2011). An analysis of the drivers affecting the implementation of green supply chain management. Resources, Conservation and Recycling, 55(6), 659-667. doi:10.1016/j.resconrec.2010.12.002

DiMaggio, P. J., \& Powell, W. W. (2013). The iron cage revisited: institutional isomorphism and collective rationality in organizational fields. American Sociological Review, 48(2). doi:10.2307/2095101

Gao. Y, J. L., Yunfeng Song. (2019). Performance evaluation of green supply chain management based on membership conversion algorithm. International Colloquium on Computing, Communication, Control, and Management. doi:10.1109/CCCM.2009.5267895

Geng, R., Mansouri, S. A., \& Aktas, E. (2017). The relationship between green supply chain management and performance: A meta-analysis of empirical evidences in Asian emerging economies. International Journal of Production Economics, 183, 245-258. doi:10.1016/j.ijpe.2016.10.008

Hervani, A. A., Helms, M. M., \& Sarkis, J. (2015). Performance measurement for green supply chain management. Benchmarking: An International Journal, 12(4), 330-353. doi:10.1108/14635770510609015

Holt, D., \& Ghobadian, A. (2019). An empirical study of green supply chain management practices amongst UK manufacturers. Journal of Manufacturing Technology Management, 207), 933-956. doi:10.1108/17410380910984212

Hong, P., Kwon, H. B., \& Jungbae Roh, J. (2019). Implementation of strategic green orientation in supply chain. European Journal of Innovation Management, 12(4), 512 532. doi: $10.1108 / 14601060910996945$

Kumar, S., \& Putnam, V. (2008). Cradle to cradle: Reverse logistics strategies and opportunities across three industry sectors. International Journal of Production Economics, 115(2), 305-315. doi:10.1016/j.ijpe.2007.11.015 
Surangi, Divakera and Amaratunge

Kung, F. H., Huang, C. L., \& Cheng, C. L. (2012). Assessing the green value chain to improve environmental performance. International Journal of Development Issues, 11(2), 111128. doi: $10.1108 / 14468951211241119$

Laosirihongthong, T., Adebanjo, D., \& Choon Tan, K. (2013). Green supply chain management practices and performance. Industrial Management \& Data Systems, 113(8), 1088-1109. doi:10.1108/imds-04-2013-0164

Liu, Y., Zhang, Y., Batista, L., \& Rong, K. (2019). Green operations- what's the role of supply chain flexibility. International Journal of Production Economics, 13.

M Porter, \& Linde, C. V. d. (1995). Green and competitive: ending the stalemate. Edward Elgar Publishing Inc.

Masoumik, S. M., Abdul-Rashid, S. H., Olugu, E. U., \& Ghazilla, R. A. R. (2015). A strategic approach to develop green supply chains. Procedia CIRP, 26, 670-676. doi:10.1016/j.procir.2014.07.091

Nadeem, K., \& Siddiqui, D. A. (2017). The effect of strategic orientation on green supply chain practices and performance: a case of manufacturing companies in Pakistan. Asian Business Review, 7(2), 59-70. doi:10.18034/abr.v7i2.12

Ninlawan C., S. P., Tossapol K., \& Pilada W. (2011a, 17 - 19 March 2020). The Implementation of Green Supply Chain Management Practices in Electronics Industry. Paper presented at the International Multiconference of Engineers and Scientists Hong Kong.

Ninlawan, C., Seksan, P., Tossapol, K., \& Pilada, W. (2011b). The implementation of green supply chain management practices in electronics industry. In World Congress on Engineering 2012. 2182, 1563-1568.

Paulraj, A. (2011). understanding the relationships between internal resources and capabilities, sustainable supply management and organizational sustainability. Journal of Supply Chain Management, 47(1), 19-37. doi:10.1111/j.1745493X.2010.03212.x

Rivera, J. (2014). Institutional pressures and voluntary environmental behavior in developing countries: evidence from the Costa Rican hotel industry. Society \& Natural Resources, 17(9), 779-797. doi:10.1080/08941920490493783

Seaman, M. N. (2012). The retromer complex - endosomal protein recycling and beyond. J Cell Sci, 125(Pt 20), 4693-4702. doi:10.1242/jcs.103440

Srivastava, S. K. (2017). Green supply-chain management: A state-of-the-art literature review. International Journal of Management Reviews, 9(1), 53-80. doi:10.1111/j.1468-2370.2007.00202.x

Sundarakani, B., de Souza, R., Goh, M., Wagner, S. M., \& Manikandan, S. (2011). Modeling carbon footprints across the supply chain. International Journal of Production Economics, 128(1), 43-50. doi:10.1016/j.ijpe.2010.01.018

Wu, Z., \& Pagell, M. (2011). Balancing priorities: decision-making in sustainable supply chain management. Journal of Operations Management, 29(6), 577-590. doi:10.1016/j.jom.2010.10.001 
South Asian Journal of Business Insights

Yildiz Çankaya, S., \& Sezen, B. (2019). Effects of green supply chain management practices on sustainability performance. Journal of Manufacturing Technology Management, 301), 98-121. doi:10.1108/jmtm-03-2018-0099

Younis, H., Sundarakani, B., \& Vel, P. (2016). The impact of implementing green supply chain management practices on corporate performance. Competitiveness Review, 26(3), 216-245. doi:10.1108/cr-04-2015-0024

Zhao, R., Liu, Y., Zhang, N., \& Huang, T. (2017). An optimization model for green supply chain management by using a big data analytic approach. Journal of Cleaner Production, 142, 1085-1097. doi:10.1016/j.jclepro.2016.03.006

Zhu, Q., \& Sarkis, J. (2011). The moderating effects of institutional pressures on emergent green supply chain practices and performance. International Journal of Production Research, 45(18-19), 4333-4355. doi:10.1080/00207540701440345

Zhu, Q., Sarkis, J., \& Lai, K.-h. (2018). Confirmation of a measurement model for green supply chain management practices implementation. International Journal of Production Economics, 111(2), 261-273. doi:10.1016/j.ijpe.2006.11.029

\section{Author Biography}

Dr H.A.K.N.S. Surangi is a Senior Lecturer at the University of Kelaniya, Sri Lanka. She completed her PhD at the University of Lincoln, United Kingdom. She has a longstanding interest in female entrepreneurship, gender, ethnic minority entrepreneurship, entrepreneurial networking and small business development in Asian countries. H.A.K.N.S. Surangi can be contacted at:surangins@kln.ac.lk

Dr.Sanath Divakara is a Mechanical Engineer by profession. He earned a Doctor of Business Administration degree in Entrepreneurship and Small Business from the University of Kelaniya and B.Eng., M.Eng (Energy Technology) and MBA (Finance) from the University of Moratuwa Sri Lanka and the University of Manipal India, respectively. He has more than 25 years of experience holding many senior positions in the corporate sector. His research interests include entrepreneurship, corporate entrepreneurship, Intrapreneurship, supply chain management and project management.

Mrs S. Amarathunge is a Senior Lecturer at the University of Kelaniya, Sri Lanka. She earned a MSc Econ (Saga-Japan), MA Econ (C'bo) and BA Econ (Sri J'pura), respectively. She has more than 26 years of experience in the academic field. Her research interest includes prevailing economic problems in developing countries and entrepreneurship. 